\title{
An Assessment of Men Semen Alterations in SARS-CoV-2: Is Fever the Principal Concern?
}

\author{
Mohamed Hadi Mohamed Abdelhamid ${ }^{1,2}$ (]) Abdulmunam A. Fellah $^{1} \cdot$ Ahmed Elmarghani $^{1,2}$. \\ Iman Amin Al msellati ${ }^{3}$
}

Received: 29 October 2021 / Accepted: 13 February 2022 / Published online: 22 February 2022

(c) Society for Reproductive Investigation 2022

\begin{abstract}
The SARS-CoV-2 virus (COVID-19) was identified as a pandemic in March 2020 by the World Health Organization. The virus spreads primarily through saliva droplets or nasal discharges, in addition to coughing or sneezing from an infected person. The most common symptom at the onset of illness is fever, which may appear within 2-14 days after exposure. The high fever (above $38^{\circ} \mathrm{C}$ ) can persist from one to 4 days. The febrile illness usually has a variable negative impact on sperm characteristics such as sperm output, motility, morphology, and DNA fragmentation. These defects proliferated due to an increase in testicular temperature, and disturbance in the thermoregulatory systems that are responsible for the testicular heat loss. Coronavirus studies suggest that fever from SARS-CoV-2 virus infection induces a reversible negative effect on the sperm parameters until one cycle (74 days) of spermatogenesis. We believe that SARS-CoV-2 can have long-term adverse effects on testicles via immune or inflammatory reactions after the patient has fully recovered. This evidence could be added to the list of the long-term post-COVID-19 syndromes. Long-term follow-up and evaluation of the sperm parameters are necessary for all recovered male patients, especially the young ones.
\end{abstract}

Keywords SARS-CoV-2 $\cdot$ COVID-19 $\cdot$ Testis temperature $\cdot$ Fever $\cdot$ Sperm parameters $\cdot$ Men

\section{Introduction}

The 2019 novel coronavirus disease (COVID-19) was first detected in December 2019 in China. COVID-19 has been rapidly spreading all over the world in February and March 2020, and was recognized as a pandemic in March 2020 by the World Health Organization [1, 2].

Human coronaviruses are endemic in human populations, causing $15-30 \%$ of respiratory tract infections each year. Prior to the outbreak of COVID-19, a highly pathogenic severe acute respiratory syndrome coronavirus (SARS-CoV) appeared between 2002 and 2003. This was followed by

Mohamed Hadi Mohamed Abdelhamid

Mohamed.abdelhamid@btc.org.ly; Moh9363@gmail.com

1 Department of Genetic Engineering, Cell Biology and Tissue Culture, Biotechnology Research Center (BTRC), Tripoli, Libya

2 National Center of Disease Control (NCDC), Tripoli, Libya

3 Primary Health Care, National Center of Disease Control (NCDC), Tripoli, Libya
Middle Eastern respiratory syndrome coronavirus (MERSCoV) between 2012 and 2015 [3].

Currently, there are about 240 million confirmed cases and 4.9 million deaths in three consecutive waves of the SARS-CoV-2 virus in 213 countries and territories around the world [4].

Furthermore, it was observed that the SARS-CoV-2 invasion of the host cell begins when the covering glycoprotein spike (S) attaches to the dipeptidyl peptidase 4 (DPP4) and angiotensin-converting enzyme 2 (ACE2)'s cellular receptors for MERS-CoV and SARS-CoV, respectively [5]. The virioncontaining vesicles are formed when the viral genomic RNA is produced in the cytoplasm, replicated, and then attached to nucleocapsid proteins and glycoproteins envelope. Subsequently, the virus is spread outside the cell by blending with the plasma membrane [5]. The viral infection from SARSCoV-2 primarily causes respiratory illness ranging from mild-to-severe disease and death. However, about $80 \%$ of the infected people never develop symptoms and may recover without any special treatment or hospitalization $[6,7]$.

The most common symptoms of patients hospitalized with COVID-19 across a broad clinical spectrum were fever, 
shortness of breath, cough, fatigue, loss of taste and smell, diarrhea, and lymphopenia [8-10].

An observational study on 1420 cases admitted to the hospital with mild or moderate disease reported that the most common symptoms were fever $(45 \%)$, headache $(70.3 \%)$, loss of smell (70.2\%), nasal obstruction (67.8\%), and cough (63.2\%) [11]. Another study of 4203 patients mostly from China identified fever, cough, and dyspnea $(80.5 \%, 58.3 \%$, and $23.8 \%$, respectively) as the most common clinical symptoms. [12]. In addition, a research group from Wuhan reported that 40 out of 41 patients admitted to the hospital with laboratory-confirmed COVID-19 had a fever as a symptom, $73 \%$ of them were men [1]. This study was consistent with the results obtained by Cao et al. described the initial clinical, laboratory, and radiological characteristics symptoms of the infected patients [13]. They conducted a study on 198 patients with COVID-19, 33.3\% of the subjects were under 39 years old, and males represented $51.0 \%$ of patients. Notably, fever was the most common symptom among those patients, with $86.9 \%$ had a body temperature ranging from 38 to $38.9^{\circ} \mathrm{C}$ and the other $8.8 \%$ had a fever greater than $39^{\circ} \mathrm{C}$ [13].

Typically, the average period of the symptoms for patients infected with COVID-19 is $11.5 \pm 5.7$ days. The occurrence of symptoms significantly differed according to age and sex [11]. However, the symptoms may last weeks or months after the infection has gone. These circumstances are called postCOVID-19 syndrome or long COVID. Certainly, the testis is one of the organs most affected by COVID-19 [14-16]. Given that spermatogenesis could be affected by COVID-19 associated fever, semen parameters such as sperm concentration and motility may decrease for a period of 72 to 90 days after the viral infection [17]. Moreover, fever is a symptom of COVID-19 diagnosed in more than $70 \%$ of cases. Thus, fever may affect testis and semen quality [18].

In men, the functions of the testis and the epididymis are highly sensitive to the temperature increase of only a few degrees [19], and considerable effort has been devoted to analyzing this response.

Several reports have demonstrated that increased body temperature by fever is a factor affecting sperm parameters [20-22]: an acute fever of $39.9-40{ }^{\circ} \mathrm{C}$ for 1 to 4 days, harmed sperm parameters such as sperm output, motility, morphology, and DNA fragmentation. This defect may lead to changes in the metabolism of the germ cells, such as a decrease in the synthesis of DNA, RNA, and proteins. In addition, testicular heating may lead to vascular changes[23].

Moreover, studies reported that exposure of scrotal/testicular to temperatures of several degrees above core body temperature $37{ }^{\circ} \mathrm{C}$ [24-29], and/or below core body temperature $35-37^{\circ} \mathrm{C}[30-36]$ may induce a disruption of spermatogenesis. This effect depends on two important factors: temperature exposure rate (high or mild) and/or the duration of heat exposure [23].

SARS-CoV-2 virus (COVID-19) is an unprecedented challenge to healthcare systems. Few studies reported the impact of the SARS-CoV-2 virus on the reproductive system, or whether it might change the sperm parameters and sexual hormones for recovered male patients. Here, we discuss the impact of the SARS-CoV-2 virus or accompanying symptoms on testes function and quality of sperm. We also exam the potential mechanisms by which the SARS-CoV-2 virus affects sperm parameters and sexual hormones for recovered male patients.

\section{Materials and Methods}

A classified and comprehensive search in previous studies in PubMed, Embase, Web of Science, Scopus, and Cochrane Library Databases was conducted in accordance with the guidelines of PRISMA (2020) (Preferred Reporting Items for Systematic Reviews and Meta-Analyses).

Literature reviews, both published and peer-reviewed existing articles in English, were studied from online publications between the years 2020 to 2021. Additional sources of citations were from retrieving articles, and there was no limitation on sample size. We reviewed all appropriate titles of all reports, including testicular heat stress and sperm quality, and male gonadal function during and after fever. Similarly, prior publications of clinical studies to coronaviruses were few numbers: articles with information regarding male reproduction, the presence of virus in reproductive tissues, and effects on gametes.

We used a comprehensive and extensive search strategy in order not to miss a formative contribution that might relate to our topic. Search keywords used for different database strategy included the following: fever, male infertility, testis, heat exposure, sperm parameters, genital heat stress, SARSCoV-2, COVID-19, viral infection, angiotensin-converting enzyme 2 receptors (ACE20), spermatogenesis, reproductive system.

\section{The Viral Infection and Male Fertility}

Viruses are known for their capability to infect testes, for example; mumps viruses were found in human Leydig cells and human immunodeficiency virus (HIV) infects human germ cells. HIV, hepatitis B virus (HBV), herpes simplex virus (HSV), and adenoviruses were detected in semen as shown in (Table 1) [37-44]. Additionally, over 20 types of viruses that infect humans have been found in semen and testis such as; Ebola, and Zika virus (ZIKV) [45, 46]. 
Table 1 Review of the literature on the influence of virus semen infection on sperm parameters

\begin{tabular}{|c|c|c|c|c|c|}
\hline Virus & Studies & $\begin{array}{l}\text { Present in } \\
\text { semen }\end{array}$ & Sperm Count & Motility & $\begin{array}{l}\text { Normal } \\
\text { morphol- } \\
\text { ogy }\end{array}$ \\
\hline HBV & Lorusso et al. [37], Zhou et al. [38], Karamolahi et al. [39] & + & $\downarrow$ & $\downarrow$ & $\downarrow$ \\
\hline $\mathrm{HCV}$ & Hofny et al. [40], Lorusso et al. [37], Safarinejad et al. [41] & + & $\downarrow$ & $\downarrow$ & $\downarrow$ \\
\hline HIV & Kehl et al. [42], Lorusso et al. [37], Pavili et al. [43] & + & $\downarrow$ & $\downarrow$ & $\downarrow$ \\
\hline HPV & Bezold et al. [44] & + & $\downarrow$ & $\downarrow$ & $\downarrow$ \\
\hline Zika & Joguet et al. [45] & + & $\downarrow$ & $\downarrow$ & $\downarrow$ \\
\hline
\end{tabular}

Review of the literature on the influence of virus semen infection on sperm parameters. $(+)$ : Positive in semen sample $(\uparrow)$ : increase. $(\downarrow)$ : decrease. (HBV): hepatitis B virus. (HCV): hepatitis C virus. (HIV): human immunodeficiency virus. (HPV): Human papillomavirus

Many studies have shown that the presence of HIV, HBV, or HCV in semen impairs sperm parameters, DNA integrity, and reduces forward motility. Other viruses, such as EpsteinBarr virus, Papillomavirus, and mumps virus, were reported to cause viral orchitis [47-49].

A study conducted in 2002 reported that six male patients infected with SARS-CoV suffered from orchitis as observed through testicular autopsy. They found that orchitis was one of the post-infectious complications that may lead to disruption in spermatogenesis, germ cell apoptosis, and consequently affecting semen quality [42].

On the other hand, Zika virus (ZIKV) has been reported to cause pathological damage in the male reproductive system and detected in the testis and epididymis several weeks after the virus has disappeared from the blood [50].

Viral infection of the testicular cells may cause changes in testicular function, risk of fertility, and general health of the individual (such as a fall in testosteronemia which may lead to cachexia), plus possible transmission of virus-induced mutations to subsequent generations [41].

\section{Genital Heat Exposure and Sperm Parameters}

In men, the physiological migration of the testis is associated with a considerable cooling of its thermal environment. This procedure results in a scrotal temperature being $2-4{ }^{\circ} \mathrm{C}$ lower than the body core temperature [23]. This lower temperature is required for the process of sperm development or spermatogenesis to proceed in normal settings.

Two main thermoregulatory systems are responsible for this lower physiological testicular temperature in human. The first system consists of a countercurrent heat exchange between arterial blood and spermatic vein blood through the pampiniform plexus [51]. The second system is the external heat loss outside the body through passive convection and radiation by the scrotum $[51,52]$. Furthermore, several characteristics of the scrotum, such as thin skin with minimal subcutaneous fat, dense sweat glands, and scant hair distribution play a role in regulating testicular temperature as well [23].
Most of the experimental protocols that raise the testicular temperature different methods (electric warming bag, polyester-lined supports, testis supra-scrotal localization, sauna, water bath) have a negative impact on spermatogenesis and the quality of sperm parameters (Table 2). An experimental increase in temperature intensity can be classified into two categories, depending on the body temperature: a mild increase when the testicular temperature remains below body temperature, and a high increase when it exceeds body temperature.

\section{The Effect of the Acute Febrile Illness (Fever) on Sperm Parameters}

During the onset of fever, testicular thermoregulation is disrupted, and scrotal temperature is raised along with the core body temperature. Several studies have shown that fever impairs spermatogenesis due to increased testicular temperature [20, 22, 52, 57-59]. Evenson et al. reported that a 1-day fever of $39.9^{\circ} \mathrm{C}$ in a fertile man presented with influenza had $36 \%, 49 \%$, and $30 \%$ denatured sperm DNA at 18,33 , and 39 days post fever, respectively, using the sperm chromatin structure assay (SCSA) (Table 3) [21]. Further, they reported alterations in the normal processing of protamine 2 and a slight increase in histone to protamine ratio suggesting a fever related disruption of mRNA synthesis which codes protamine 2 processing enzyme.

MacLeod followed three medical students during a febrile disease (body temperature was $37.7-40^{\circ} \mathrm{C}$ ) of chickenpox and pneumonia and found a marked decrease in sperm concentration, morphology and motility, and recovery almost 1-2 months after normalization of the temperature [60].

Sergerie et al. showed that fever may affect sperm parameters (total sperm count, motility, and vitality) and DNA fragmentation index (DFI) in a fertile man. Semen parameters were analyzed at $15,37,58,79$, and $>180$ days after the fever [22]. Total sperm count significantly decreased from 15 to 58 days from the onset of fever and recovered on day 79 post fever. In addition, the percentage of sperm motility significantly decreased on day 15 and 37 and returned to 
Table 2 The effects of experimental scrotal/ testicular temperature increase on sperm parameters

\begin{tabular}{|c|c|c|c|c|c|c|c|}
\hline Research group & Method of heating & $N$ & $H /$ days & Period & $\begin{array}{l}\text { Started effects } \\
\text { during } \mathrm{T}^{\circ} \\
\text { Increase }\end{array}$ & $\begin{array}{l}\text { Recovery after } \mathrm{T}^{\circ} \\
\text { increase }\end{array}$ & Parameter \\
\hline $\begin{array}{l}\text { Robinson and Rock } \\
\text { [53] }\end{array}$ & Cloth-insulation & 10 fertile men & $11 \mathrm{H}$ & $10 \mathrm{~W}$ & $3 \mathrm{~W}$ During T & $11 \mathrm{~W}$ after $\mathrm{T}$ & Count $(\downarrow)$ \\
\hline $\begin{array}{l}\text { (1) Mieusset et al. [54, } \\
55]\end{array}$ & STP & 14 fertile men & $15 \mathrm{H}$ & $12 \mathrm{M}$ & $2 \mathrm{M}$ During $\mathrm{T}$ & 6-8 $\mathrm{M}$ after $\mathrm{T}$ & $\begin{array}{l}\text { volume }(\downarrow) \\
\text { Count }(\downarrow) \\
\text { Morphology }(\downarrow) \\
\text { Motility }(\downarrow)\end{array}$ \\
\hline${ }^{(2)}$ Mieusset et al. [56] & STP & 6 fertile men & $15 \mathrm{H}$ & $6-24 \mathrm{M}$ & $2 \mathrm{M}$ During $\mathrm{T}$ & $6-15 \mathrm{M}$ after $\mathrm{T}$ & $\begin{array}{l}\operatorname{Count}(\downarrow) \\
\text { Morphology }(\downarrow) \\
\text { Motility }(\downarrow)\end{array}$ \\
\hline Shafik [32] & Polyester-insulation & 28 Men & $24 \mathrm{H}$ & $12 \mathrm{M}$ & $\begin{array}{l}3 \mathrm{M} \\
\text { During } \mathrm{T}\end{array}$ & $6 \mathrm{M}$ after $\mathrm{T}$ & $\begin{array}{l}\text { Count }(\downarrow) \\
\text { Morphology }(\downarrow) \\
\text { Motility }(\downarrow)\end{array}$ \\
\hline Shafik [33] & Polyester-insulation & 14 men & $24 \mathrm{H}$ & $12 \mathrm{M}$ & $3 \mathrm{M}$ & $6 \mathrm{M}$ after $\mathrm{T}$ & $\begin{array}{l}\text { Count }(\downarrow) \\
\text { Testicular Volume }(\downarrow)\end{array}$ \\
\hline Zhang et al. [29] & Water bag & 19 fertile men & $\mathrm{H} / \mathrm{D}$ & $3 \mathrm{M}$ & $\begin{array}{l}1 \mathrm{M} \\
\text { During } \mathrm{T}\end{array}$ & $1 \mathrm{M}$ after $\mathrm{T}$ & $\begin{array}{l}\text { Count }(\downarrow) \\
\text { Morphology }(\downarrow) \\
\text { Motility }(\downarrow) \\
\text { WBC }(\uparrow)\end{array}$ \\
\hline Ahmad et al. [34] & STP & 5 fertile men & $15 \mathrm{H}$ & $4 \mathrm{M}$ & $\begin{array}{l}34 \mathrm{D} \\
\text { During T }\end{array}$ & $93 \mathrm{D}$ after $\mathrm{T}$ & $\begin{array}{l}\text { Count }(\downarrow) \\
\text { Motility }(\downarrow) \\
\text { Round Cell }(\uparrow) \\
\text { Viability }(\downarrow) \\
\text { DFI }(\uparrow) \\
\text { HDS }(\uparrow)\end{array}$ \\
\hline
\end{tabular}

${ }^{(1)}$ Ensure the permanent localization of the testes close to the inguinal canal but testicles were relatively free to travel due to the elasticity of the fabric. STP supra-scrotal position, $W B C$ white blood cells, $N$ subject number, $H$ hour, $W$ week, $M$ month, $D$ days, $T$ temperature, $D F I$ DNA fragmentation index, HDS high DNA stainability. $(\uparrow)$ : increase. $(\downarrow)$ : decrease. Ensure the permanent localization of the testes close to the inguinal canal but testicles were relatively free to travel due to the elasticity of the fabric

${ }^{(2)}$ Add to the device a ring of soft material to ensure that the testicles were kept permanently in an inguinal position. STP supra-scrotal position, $W B C$ white blood cells, $N$ subject number, $H$ : hour, $W$ week, $M$ month, $D$ days, $T$ temperature, $D F I$ DNA fragmentation index, $H D S$ high DNA stainability. $(\uparrow)$ : increase. $(\downarrow)$ : decrease

Table 3 The effects of febrile episodes (fever) on testis, scrotal, and sperm parameters

\begin{tabular}{|c|c|c|c|c|}
\hline Research group & Body $\mathrm{T}^{\circ}$ & $\mathrm{N}$ & $\mathrm{H} /$ days & Parameters \\
\hline Lazarus and Zorgniotti [52] & $37.6-37.9^{\circ} \mathrm{C}$ & 6 men & $(-)$ & Intra-scrotal temperature $(\uparrow)$ \\
\hline Buch and Havlovec [59] & $38.3^{\circ} \mathrm{C}$ & 14 fertile men & $24 \mathrm{H}$ & $\operatorname{Count}(\downarrow)$ \\
\hline Evenson et al. [21, 57] & $39.9^{\circ} \mathrm{C}$ & One case study & $24 \mathrm{H}$ & $\begin{array}{l}\text { DFI }(\uparrow) \\
\text { HDS }(\uparrow) \\
\text { Free -SH }(\uparrow)\end{array}$ \\
\hline French et al. [20] & $40^{\circ} \mathrm{C}$ & One case study & 3 days & Sperm density $(\downarrow)$ \\
\hline Sergerie et al. [22] & $39-40^{\circ} \mathrm{C}$ & One case study & 2 days & $\begin{array}{l}\text { Count }(\downarrow) \\
\text { Motility }(\downarrow) \\
\text { DFI }(\uparrow) \\
\text { HDS }(\uparrow)\end{array}$ \\
\hline Carlsen et al. [58] & $(-)$ & 15 men & 1-11 days & $\begin{array}{l}\text { Count }(\downarrow) \\
\text { Morphology }(\downarrow) \\
\text { Motility }(\downarrow)\end{array}$ \\
\hline MacLeod [60] & $37.7-40^{\circ} \mathrm{C}$ & 3 men & 3-5 days & $\begin{array}{l}\text { Count }(\downarrow) \\
\text { Morphology }(\downarrow) \\
\text { Motility }(\downarrow)\end{array}$ \\
\hline
\end{tabular}

$N$ subject number, $H$ hour, $D$ days, $T^{\circ}$ temperature, $D F I$ DNA fragmentation index, $H D S$ high DNA stainability. $(-)$ : no date. $(\uparrow)$ : increase. $(\downarrow)$ : decrease 
normal on day 58-post fever. DFI measured by the sperm chromatin structure assay (SCSA) significantly increased by $24 \%$ and $36 \%$ and by 15 and 37 days, post fever, respectively. However, They decreased to $15 \%$ and $8 \%$ when approached to 58 and 79 days, post fever, respectively [22].

In the same context, Carlsen et al. analyzed the effect of a history of febrile illness on semen quality in men who experienced one or more episodes of fever. Sperm concentration, morphology, and motility are significantly affected by fever, particularly during the post-meiotic period of spermiogenesis. In addition, the number of days the men experienced fever significantly affected their sperm parameters [58].

Other publications have analyzed the effect of temperature on semen quality. Buch and Havlovec (1991) found that sperm count has decreased in a case report of a semen donor of the patient who suffered an acute viral illness with a fever $\left(38.3^{\circ} \mathrm{C}\right.$ for $\left.24 \mathrm{~h}\right)$ [59]. Another study reported that the Intra-scrotal temperature was compared with oral body temperature in six subjects with fever; when the body temperature reached 37.6 to $37.9^{\circ} \mathrm{C}$, the testicular thermoregulatory mechanism appeared to fail, and the intra-scrotal temperature increased. However, the adverse effect seemed to be dependent upon the number of days with fever [52].

Several studies have reported a rise in testicular temperature resulting from fever has induced a reversible decrease in sperm output and quality (motility, normal morphology) as well as in fertility when exposure ranges up to 2 days.

\section{SARS-CoV-2 (COVID-19) and Male Fertility}

Statements reported a high rate of infection, morbidity, and mortality among male patients who tested positive for coronavirus. However, very few casuistic reports were conducted on men to show the effects of COVID-19 on sperm parameters, sexual hormones, and the male reproductive system.

To date, most studies reported that the SARS-CoV-2 virus is absent from the semen and testes in men infected in both acute and recovery phases [61-67].

In contrast, a study of 38 male patients with the SARSCoV-2 virus found that 4 of 15 patients $(26.7 \%)$ were in an acute stage of infection and 2 of 23 patients $(8.7 \%)$ in recovery had detectable SARS-CoV-2 presents in semen samples [68]. Similarly, Yang et al. reported that one case (1/12) with a high viral load was positive for viral RNA after post-mortem examinations of testicular tissue [16].

Furthermore, studies have identified the main path for coronavirus entry into the cell-via the viral spike (S) protein that is attached to the angiotensin-converting enzyme 2 (ACE2). Interestingly, at the level of testicular cells, four main cell types, such seminiferous duct cells, spermatogonia, Leydig cells, and Sertoli cells, show a higher rate of ACE2 mRNA expression, where it employs the cellular serine protease (TMPRSS2) for S protein priming both of which present in the testis. Thus, concern has arisen regarding (1) infection of the testes [69] and (2) possible sexual transmission [70]. However, no experimental studies or epidemiological investigations have described evidence that COVID-19 is a sexually transmitted disease (STD). While angiotensin-converting enzyme 2 receptors were found in the reproductive organs, the lack of co-expression of the TMPRSS2 modulator protein, required for SARS-CoV-2 cell entry, in testicular cells, sperm, or seminal plasma, argues against the hypothesis that gametes may transmit SARSCoV-2 [18, 67].

In a recent study, the results reported that the testosterone to luteinizing hormone ( $\mathrm{T}$ to $\mathrm{LH}$ ) ratio in 81 patients with the SARS-CoV-2 virus was dramatically decreased in comparison with 100 age-matched healthy counterparts. Serum $\mathrm{T}$ to $\mathrm{LH}$ ratio (as a predictor of Leydig function) could be a potential marker of impairment of reproductive health in COVID-19 patients [70, 71]. One observation in Hamburg, Germany, showed that majority of male SARS-CoV-2 virus patients present with low testosterone and dihydrotestosterone levels at admission to the intensive care unit (ICU). In addition, 6 out of the 35 male patients with low testosterone levels have elevated levels of the luteinizing hormone (LH) at the same time, suggesting impairment of Leydig cell steroidogenesis in $17.1 \%$ of the male patients [72]. Furthermore, an acute critical inflammatory condition, as in the case of COVID-19, may suppress the activity of hypothalamic-pituitary-testicular (HPT) axis. These findings may suggest direct effects of SARS-CoV-2 virus infection in testicular cells rather than via the HPT axis [73].

Moreover, the hyperactivated immune responses along with cytokine storms following SARS-CoV-2 infection affect many organs. There is a direct correlation between an increase in pro-inflammatory cytokines and multiple-organ failure, including the heart, liver, and kidney. In addition, a high inflammatory response associated with fever, immune cell activation, and inflammatory mediators such as interferons and cytokines can affect testicular function (Fig. 1) $[74,75]$.

Importantly, fever is an additional risk of COVID19 that may affect male fertility. The average duration of fever in SARS-CoV and SARS-CoV-2 patients is the same (11.4 \pm 6.8 days) and it may last for 31 days in COVID19 patients who receive intensive care services (ICU) [76]. However, the duration of fever observed in MERS and other viruses such as influenza and Zika virus was shorter; the average duration of MERS is 8 days [76-78], the influenza is 3-4 days for the influenza virus [79], and Zika virus was 1-8 days. [80]. Hence, we can conclude that the fever caused by COVID-19 may have a significant effect compared to other viruses.

Within the same family of SARS-CoV-2 virus, Xu et al. stated that pyrexia is a first symptom expressed in SARS 
Fig. 1 Schematic overview of the mechanism of the increase in body temperature (fever)induced SARS-CoV-2 infection. TNF- $\alpha$ and IFN- $\Upsilon$ synergize to drive the cytokine storm and fever associated with COVID19 to impair sperm quality. Created by BioRender.com

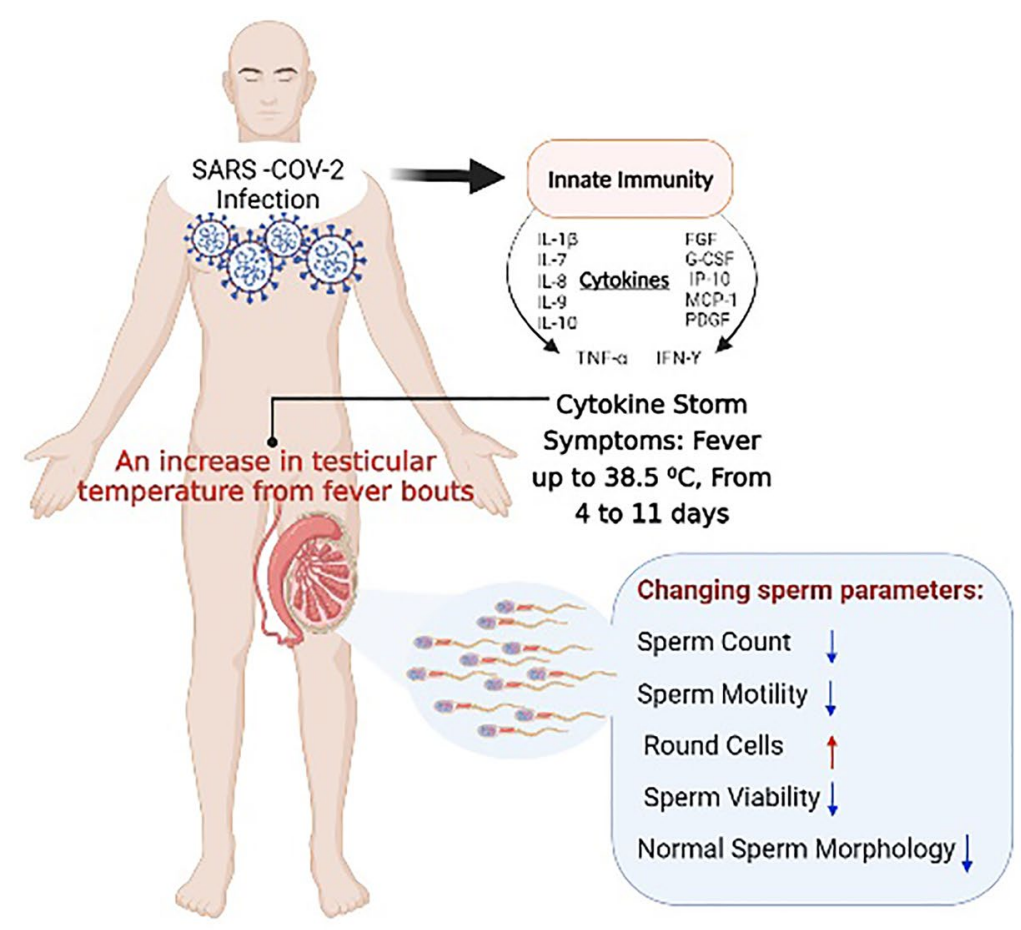

Created in BioRender.com bio patients combined with increased apoptotic spermatogenetic cells and a few positive Leydig cells as shown in (Fig. 1) [49].

A recently conducted study by Patel et al. reported that spermatogenesis could be affected by COVID-19-associated fever, and semen parameters such as sperm concentration, morphology, and motility could be decreased at least one cycle of spermatogenesis (74 days) after the viral infection [17]. Additionally, Temiz et al. showed a significant decrease in the percentage of normal morphology of the semen in patients infected with the COVID-19; they attributed this result to the fever seen in all COVID-19 patients [18].

Certainly, it seems prudent to avoid pregnancy if the risk of COVID-19 infection remains high for many of COVID-19 actions have not yet been discovered. The American Society for Reproductive Medicine (ASRM) and the European Society of Human Reproduction and Embryology (ESHRE) issued a recommendation for the patient and clinical management during the coronavirus (COVID-19) pandemic. Similarly, initiation of new treatment cycles, including ovulation induction, intrauterine inseminations (IUIs), and in vitro fertilization (IVF) including retrievals and frozen embryo transfers, as well as non-urgent gamete cryopreservation should be avoided. Also, strongly consider the cancellation of all embryo transfers whether fresh or frozen [81].

There are at least three possible speculations on how the SARS-CoV-2 virus can affect testicular functions and sperm quality: (1) body fever contributes to an increase in testicular temperature which may cause poor sperm quality, this notion has been generally accepted. Several authors showed a negative influence of fever on semen quality with impaired sperm density, progressive motility, and morphology occurring a few weeks after the onset of fever and lasting for 1-3 months [20, 21, 23, 58-60, 82] (Fig. 1). (2) Triggering a secondary autoimmune response leading to autoimmune orchitis [73]. (3) The SARS-CoV-2 binds to the ACE2 receptors for cellular entry and replication. Thus, it may be observed that testicular cells with higher ACE2 expression are more susceptible to the effects of SAR-CoV-2 [83].

\section{Conclusions}

COVID-19 affects a wide-range of patients, from youth to the elderly. Fever is consistently the most common symptom of onset, and several studies demonstrated that males are more likely to be infected by COVID-19 and more likely to die. One important aspect of our review is the highlight of one of the COVID-19 virus symptoms (fever) that may affect men's sperm parameters post-recovery of the illness. Physicians must counsel patients about the risk of damage to the testis's cells, sperm parameters, and sperm DNA fragmentation, especially those who had been exposed to severe fever. We recommend adding the effect of the SARS-CoV-2 virus on the testis and on the quality of sperm to the list of 
the post-COVID-19 syndrome (long COVID), which may last up to 3 months post-recovery.

Today, the impact of COVID-19 on male fertility is vague in several aspects. Well-designed and controlled studies of reproductive function and evaluation of the sperm quality may be required for men recovered from COVID-19 disease, especially young male patients.

Acknowledgements We thank Prof. Louis Bujan of the Human Fertility Research Group, Universite Paul Sabatier, Toulouse, who have given insights for the writing of this paper. The author wishes to thank Dr. Hamza Ethelb and Dr. Alaa Abdelhamid for their technical support.

Author Contribution (I) Manuscript writing: all authors. (II) Final approval of manuscript: all authors.

\section{Declarations}

Conflict of Interest The authors declare no competing interests.

\section{References}

1. Huang C, Wang Y, Li X, et al. Clinical features of patients infected with 2019 novel coronavirus in Wuhan, China. Lancet. 2020;395:497-506. https://doi.org/10.1016/S0140-6736(20) 30183-5.

2. Liu H, Wang LL, Zhao SJ et al (2020) Why are pregnant women susceptible to COVID-19? An immunological viewpoint. J Reprod Immunol 139

3. Tesarik J. After corona : there is life after the pandemic. Reprod Biomed Online. 2020. https://doi.org/10.1016/j.rbmo.2020.04. 002.

4. Ministry of Health of Rwanada (2021) COVID-19 Weekly Epidemiological Update. World Heal Organ 1-33

5. Swelum AA, Shafi ME, Albaqami NM et al (2020) COVID-19 in Human, animal, and environment: a review. Front Vet Sci 7

6. Day M. Covid-19: four fifths of cases are asymptomatic, China figures indicate. BMJ. 2020;369: m1375. https://doi.org/10.1136/ bmj.m1375.

7. World Health Organization (2021) WHO COVID-19 global table data January 1 st 2021 at 5

8. Rico-Mesa JS, White A, Anderson AS (2020) Outcomes in patients with COVID-19 infection taking ACEI/ARB. Curr Cardiol Rep 22

9. Adhikari SP, Meng S, Wu Y et al (2020) A scoping review of 2019 Novel coronavirus during the early outbreak period: epidemiology, causes, clinical manifestation and diagnosis, prevention and control. 1-12. https://doi.org/10.21203/rs.2.24474/v1

10. Hoffmann M, Kleine-Weber H, Schroeder S, et al. SARS-CoV-2 cell entry depends on ACE2 and TMPRSS2 and is blocked by a clinically proven protease inhibitor. Cell. 2020;271-280. https:// doi.org/10.1016/j.cell.2020.02.052.

11. Lechien JR, Chiesa-Estomba CM, Place S, et al. Clinical and epidemiological characteristics of 1420 European patients with mild-to-moderate coronavirus disease 2019. J Intern Med. 2020;288:335-44. https://doi.org/10.1111/joim.13089.

12. Zhang JJY, Lee KS, Ang LW, et al. Risk factors for severe disease and efficacy of treatment in patients infected with COVID-19: a systematic review, meta-analysis, and meta-regression analysis. Clin Infect Dis. 2020;19:1-8. https://doi.org/10.1093/cid/ciaa576.
13. Cao M, Zhang D, Wang Y et al (2020) Clinical features of patients infected with the 2019 novel coronavirus (COVID-19) in Shanghai, China. medRxiv

14. Deshmukh V, Motwani R, Kumar A, et al. Histopathological observations in COVID-19: a systematic review. J Clin Pathol. 2021;74:76-83. https://doi.org/10.1136/jclinpath-2020-206995.

15. Ma X, Guan C, Chen R, et al. Pathological and molecular examinations of postmortem testis biopsies reveal SARS-CoV-2 infection in the testis and spermatogenesis damage in COVID19 patients. Cell Mol Immunol. 2021;18:487-9. https://doi.org/ 10.1038/s41423-020-00604-5.

16. Yang M, Chen S, Huang B, et al. Pathological findings in the testes of COVID-19 patients: clinical implications. Eur Urol Focus. 2020;6:1124-9. https://doi.org/10.1016/j.euf.2020.05. 009.

17. Patel DP, Guo J, Hotaling JM. The jury is still out: COVID-19 and male reproduction. Fertil Steril. 2020;114:257-8.

18. Temiz MZ, Dincer MM, Hacibey I, et al. Investigation of SARS$\mathrm{CoV}-2$ in semen samples and the effects of COVID-19 on male sexual health by using semen analysis and serum male hormone profile: a cross-sectional, pilot study. Andrologia. 2021;53:1-9. https://doi.org/10.1111/and.13912.

19. Bedford JM. Effects of elevated temparature on the epididymis and testis: experimental studies. Adv Exp Med Biol. 1991;286:19-32. https://doi.org/10.1007/978-1-4684-5913-5_3.

20. French DJ, Leeb CS, Jecht EW. Reduction in sperm output by febrile attacks of familial Mediterranean fever: a case report. Fertil Steril. 1973;24:490-3. https://doi.org/10.1016/S0015-0282(16) 39739-4.

21. Evenson DP, Jost LK, Corzett M, Balhorn R. Characteristics of human sperm chromatin structure following an episode of influenza and high fever: a case study. J Androl. 2000;21:739-46. https://doi.org/10.1002/j.1939-4640.2000.tb02142.x.

22. Sergerie M, Mieusset R, Croute F, et al. High risk of temporary alteration of semen parameters after recent acute febrile illness. Fertil Steril. 2007;88:970.e1-970.e7. https://doi.org/10.1016/j. fertnstert.2006.12.045.

23. Mieusset R, Bujan L. Testicular heating and its possible contributions to male infertility: a review. Int J Androl. 1995;18:169-84. https://doi.org/10.1111/j.1365-2605.1995.tb00408.x.

24. Zhang MH, Zhai LP, Fang ZY, et al. Impact of a mild scrotal heating on sperm chromosomal abnormality, acrosin activity and seminal alpha-glucosidase in human fertile males. Andrologia. 2018;50:1-12. https://doi.org/10.1111/and.12985.

25. Rao M, Zhao XL, Yang J, et al. Effect of transient scrotal hyperthermia on sperm parameters, seminal plasma biochemical markers, and oxidative stress in men. Asian J Androl. 2015;17:668-75. https://doi.org/10.4103/1008-682X.146967.

26. Zhang MH, Zhai LP, Fang ZY, et al. Effect of scrotal heating on sperm quality, seminal biochemical substances, and reproductive hormones in human fertile men. J Cell Biochem. 2018;119:10228-38. https://doi.org/10.1002/jcb.27365.

27. Robinson D, Rock J, Menkin MF. Control of human spermatogenesis by induced changes of intrascrotal temperature. JAMA J Am Med Assoc. 1968;204:290-7. https://doi.org/10.1001/jama. 1968.03140170006002.

28. Garolla A, Pizzol D, Bertoldo A, et al. Sperm viral infection and male infertility: focus on HBV, HCV, HIV, HPV, HSV, HCMV, and AAV. J Reprod Immunol. 2013;100:20-9. https://doi.org/10. 1016/j.jri.2013.03.004

29. Zhang MH, Da SZ, Yu JC, et al. Scrotal heat stress causes sperm chromatin damage and cysteinyl aspartate-spicific proteinases 3 changes in fertile men. J Assist Reprod Genet. 2015;32:747-55. https://doi.org/10.1007/s10815-015-0451-0.

30. Mieusst R, Bujan L, Mansat A, et al. Hyperthermia and human spermatogenesis: enhancement of the inhibitory effect obtained 
by 'artificial cryptorchidism.' Int J Androl. 1987;10:571-80. https://doi.org/10.1111/j.1365-2605.1987.tb00356.x.

31. Mieusset R, Grandjean H, Mansat A, Pontonnier F. Inhibiting effect of artificial cryptorchidism on spermatogenesis. Fertil Steril. 1985;43:589-94. https://doi.org/10.1016/S00150282(16)48502-X.

32. Shafik A. Testicular suspension as a method of male contraception: technique and results. Adv Contracept Deliv Syst. 1991;7:269-79.

33. Shafik A. Contraceptive efficacy of polyester-induced azoospermia in normal men. Contraception. 1992;45:439-51. https:// doi.org/10.1016/0010-7824(92)90157-O.

34. Ahmad G, Moinard N, Esquerr-Lamare C, et al. Mild induced testicular and epididymal hyperthermia alters sperm chromatin integrity in men. Fertil Steril. 2012;97:546-53. https://doi.org/ 10.1016/j.fertnstert.2011.12.025.

35. Abdelhamid MHM, Walschaerts M, Ahmad G et al (2019) Mild experimental increase in testis and epididymis temperature in men: effects on sperm morphology according to spermatogenesis stages. Transl Androl Urol 8:651-665. https://doi.org/10. 21037/tau.2019.11.18

36. Abdelhamid MHM, Esquerre-Lamare C, Walschaerts M, et al. Experimental mild increase in testicular temperature has drastic, but reversible, effect on sperm aneuploidy in men: a pilot study. Reprod Biol. 2019;19. https://doi.org/10.1016/j.repbio.2019.06. 001.

37. Lorusso F, Palmisano M, Chironna M, et al. Impact of chronic viral diseases on semen parameters. Andrologia. 2010;42(2):121-6.

38. Zhou XP, Hu XL, Zhu YM, et al. Comparison of semen quality and outcome of assisted reproductive techniques in Chinese men with and without hepatitis B. Asian J Androl. 2011;13:465-9. https://doi.org/10.1038/aja.2010.164.

39. Karamolahi S, Yazdi RS, Zangeneh M et al (2019) Impact of hepatitis $B$ virus and hepatitis $C$ virus infection on sperm parameters of infertile men. Int J Reprod Biomed 17:551-556. https://doi.org/ 10.18502/ijrm.v17i8.4820

40. Hofny ERM, Ali MEM, Taha EA, et al. Semen and hormonal parameters in men with chronic hepatitis $\mathrm{C}$ infection. Fertil Steril. 2011;95:2557-9. https://doi.org/10.1016/j.fertnstert.2011.05.014.

41. Safarinejad MR, Kolahi AA, Iravani S. Evaluation of semen variables, sperm chromosomal abnormalities and reproductive endocrine profile in patients with chronic hepatitis C. BJU Int. 2010;105:79-86. https://doi.org/10.1111/j.1464-410X.2009. 08720.x.

42. Kehl S, Weigel M, Müller D, et al. HIV-infection and modern antiretroviral therapy impair sperm quality. Arch Gynecol Obstet. 2011;284:229-33. https://doi.org/10.1007/s00404-011-1898-6.

43. Pavili L, Daudin M, Moinard N, et al. Decrease of mitochondrial DNA level in sperm from patients infected with human immunodeficiency virus-1 linked to nucleoside analogue reverse transcriptase inhibitors. Fertil Steril. 2010;94:2151-6. https://doi.org/ 10.1016/j.fertnstert.2009.12.080.

44. Bezold G, Politch JA, Kiviat NB, et al. Prevalence of sexually transmissible pathogens in semen from asymptomatic male infertility patients with and without leukocytospermia. Fertil Steril. 2007;87:1087-97. https://doi.org/10.1016/j.fertnstert.2006.08. 109.

45. Joguet G, Mansuy JM, Matusali G, et al. Effect of acute Zika virus infection on sperm and virus clearance in body fluids: a prospective observational study. Lancet Infect Dis. 2017;17:1200-8. https://doi.org/10.1016/S1473-3099(17)30444-9.

46. Koukila-Kahkola P, Paulin L, Brander E, et al. Characterisation of a new isolate of Mycobacterium shimoidei from Finland. J Med Microbiol. 2000;49:937-40. https://doi.org/10.1099/ 0022-1317-49-10-937.
47. Dejucq N, Jégou B. Viruses in the mammalian male genital tract and their effects on the reproductive system. Microbiol Mol Biol Rev. 2001;65:208-31. https://doi.org/10.1128/mmbr.65.2.208231.2001.

48. Barták V. Sperm count, morphology and motility after unilateral mumps orchitis. J Reprod Fertil. 1973;32:491-4. https://doi.org/ 10.1530/jrf.0.0320491.

49. Xu J, Qi L, Chi X, et al. Orchitis: A complication of severe acute respiratory syndrome (SARS). Biol Reprod. 2006;74:410-6. https://doi.org/10.1095/biolreprod.105.044776.

50. Liu W, Han R, Wu H, Han D (2018) Viral threat to male fertility. Andrologia 50

51. Ismail E, Orlando G, Pompa P et al (2014) Time-domain analysis of scrotal thermoregulatory impairment in varicocele. Front Physiol 5 AUG:1-11. https://doi.org/10.3389/fphys.2014.00342

52. Lazarus BA, Zorgniotti AW. Thermoregulation of the human testis. Fertil Steril. 1975;26:757-9. https://doi.org/10.1016/s00150282(16)41289-6.

53. Robinson D, Rock J. Intrascrotal hyperthermia induced by scrotal insulation: effect on spermatogenesis. Obstet Gynecol 1967;29:217-23.

54. Mieusset R, Grandjean H, Mansat A, et al. Inhibiting effect of artificial cryptorchidism on spermatogenesis. Fertil Steril 1985;43:589-94.

55. Mieusset R, Bujan L, Mansat A, et al. Effects of artificial cryptorchidism on sperm morphology. Fertil Steril 1987a;47:150-5.

56. Mieusset R, Bujan L, Mansat A, et al. Hyperthermia and human spermatogenesis: enhancement of the inhibitory effect obtained by artificial cryptorchidism. Int J Androl 1987b;10:571-80.

57. Evenson DP, Jost LK, Corzett M, Balhorn R (2000) Characteristics of human sperm chromatin structure following an episode of influenza and high fever: a case study

58. Carlsen E, Andersson AM, Petersen JH, Skakkebæk NE. History of febrile illness and variation in semen quality. Hum Reprod. 2003;18:2089-92. https://doi.org/10.1093/humrep/deg412.

59. Buch JP, Havlovec SK. Variation in sperm penetration assay related to viral illness. Fertil Steril. 1991;55:844-6. https://doi. org/10.1016/S0015-0282(16)54262-9.

60. MacLeod J. Effect of chickenpox and of pneumonia on semen quality. Fertil Steril. 1951;2:523-33. https://doi.org/10.1016/ s0015-0282(16)30726-9.

61. Holtmann N, Edimiris P, Andree M, et al. Assessment of SARS-CoV-2 in human semen-a cohort study. Fertil Steril. 2020;114:233-8. https://doi.org/10.1016/j.fertnstert.2020.05.028.

62. Song C, Wang Y, Li W, et al. Absence of 2019 novel coronavirus in semen and testes of COVID-19 patients. Biol Reprod. 2020;103:4-6.

63. Pan F, Xiao X, Guo J, et al. No evidence of severe acute respiratory syndrome-coronavirus 2 in semen of males recovering from coronavirus disease 2019. Fertil Steril. 2020;113:1135-9. https:// doi.org/10.1016/j.fertnstert.2020.04.024.

64. Guo L, Zhao S, Li W, et al. Absence of SARS-CoV-2 in semen of a COVID-19 patient cohort. Andrology. 2021;9:42-7. https://doi. org/10.1111/andr.12848.

65. Omolaoye TS, Adeniji AA, Cardona Maya WD, du Plessis SS. SARS-COV-2 (Covid-19) and male fertility: where are we? Reprod Toxicol. 2021;99:65-70. https://doi.org/10.1016/j.repro tox.2020.11.012.

66. Paoli D, Pallotti F, Colangelo S, et al. Study of SARS-CoV-2 in semen and urine samples of a volunteer with positive nasopharyngeal swab. J Endocrinol Invest. 2020;43:1819-22. https:// doi.org/10.1007/s40618-020-01261-1.

67. Tur-Kaspa I, Tur-Kaspa T, Hildebrand G, Cohen D. COVID-19 may affect male fertility but is not sexually transmitted: a systematic review. F S Rev. 2021. https://doi.org/10.1016/j.xfnr.2021.01. 002. 
68. Li D, Jin M, Bao P, et al. Clinical characteristics and results of semen tests among men with coronavirus disease 2019. JAMA Netw Open. 2020;3: e208292. https://doi.org/10.1001/jamanetwor kopen.2020.8292.

69. Tian Y, Zhou L-Q (2021) Evaluating the impact of COVID-19 on male reproduction. https://doi.org/10.1530/REP

70. Ma L, Xie W, Li D et al (2020) Effect of SARS-CoV-2 infection upon male gonadal function: a single center-based study

71. Wang S, Zhou X, Zhang T, Wang Z. The need for urogenital tract monitoring in COVID-19. Nat Rev Urol. 2020;17:314-5. https:// doi.org/10.1038/s41585-020-0319-7.

72. Schroeder M, Tuku B, Jarczak D, et al. The majority of male patients with COVID-19 present low testosterone levels on admission to Intensive Care in Hamburg. Germany: A retrospective cohort study. medRxiv; 2020.

73. Dutta S, Sengupta P. SARS-CoV-2 and male infertility: possible multifaceted pathology. Reprod Sci. 2021;28:23-6. https://doi.org/ 10.1007/s43032-020-00261-z.

74. Ragab D, Salah Eldin H, Taeimah M, et al. The COVID-19 cytokine storm; what we know so far. Front Immunol. 2020;11:14. https://doi.org/10.3389/fimmu.2020.01446.

75. Karki R, Sharma BR, Tuladhar S, et al. Synergism of TNF- $\alpha$ and IFN- $\gamma$ Triggers inflammatory cell death, tissue damage, and mortality in SARS-CoV-2 Infection and cytokine shock syndromes. Cell. 2021;184:149-168.e17. https://doi.org/10.1016/j.cell.2020. 11.025 .

76. Chen J, Qi T, Liu L, et al. Clinical progression of patients with COVID-19 in Shanghai, China. J Infect. 2020;80:e1-6. https:// doi.org/10.1016/j.jinf.2020.03.004.
77. Zhong NS, Zheng BJ, Li YM, et al. Epidemiology and cause of severe acute respiratory syndrome (SARS) in Guangdong, People's Republic of China, in February, 2003. Lancet. 2003;362:1353-8. https://doi.org/10.1016/S0140-6736(03) 14630-2.

78. Lau SKP, Woo PCY, Yip CCY, et al. Coronavirus HKU1 and other coronavirus infections in Hong Kong. J Clin Microbiol. 2006;44:2063-71. https://doi.org/10.1128/JCM.02614-05.

79. Mawatari M, Saito R, Hibino A, et al. Effectiveness of four types of neuraminidase inhibitors approved in Japan for the treatment of influenza. PLoS ONE. 2019;14:1-18. https://doi.org/10.1371/ journal.pone.0224683.

80. Zanluca C, De Melo VCA, Mosimann ALP, et al. First report of autochthonous transmission of Zika virus in Brazil. Mem Inst Oswaldo Cruz. 2015;110:569-72. https://doi.org/10.1590/007402760150192.

81. La Marca A, Niederberger C, Pellicer A, Nelson SM. COVID-19: lessons from the Italian reproductive medical experience. Fertil Steril. 2020;113:920-2. https://doi.org/10.1016/j.fertnstert.2020. 03.021.

82. Sheriff DS. Semen analyses in Hansen's disease. Trans R Soc Trop Med Hyg. 1987;81:113-4. https://doi.org/10.1016/0035-9203(87) 90299-9.

83. Achua JK, Chu KY, Khodamoradi K, Delma KS, Iakymenko OA, et al. Histopathology and ultrastructural findings of fatal COVID19 infections On testis. World J Men's Health. 2020;396:320-32. https://doi.org/10.1016/S0140-6736(20)31305-2. 